\title{
Influence of nutrients, submerged macrophytes and zooplankton grazing on phytoplankton biomass and diversity along a latitudinal gradient in Europe
}

\author{
Koenraad Muylaert • Carmen Pérez-Martínez • Pedro Sánchez-Castillo • \\ Torben L. Lauridsen • Maarten Vanderstukken • Steven A. J. Declerck • \\ Katleen Van der Gucht · José-Maria Conde-Porcuna • Erik Jeppesen • \\ Luc De Meester · Wim Vyverman
}

Published online: 11 July 2010

(C) The Author(s) 2010. This article is published with open access at Springerlink.com

\begin{abstract}
In order to evaluate latitudinal differences in the relationship of phytoplankton biomass and diversity with environmental conditions in shallow lakes, we sampled 98 shallow lakes from three European regions: Denmark (DK), Belgium/The Netherlands (BNL) and southern Spain (SP). Phytoplankton biomass increased with total phosphorus (TP) concentrations and decreased with submerged macrophyte cover across the three regions. Generic richness was significantly negatively related to submerged macrophyte cover and related environmental
\end{abstract}

Guest Editors: L. Naselli-Flores \& G. Rossetti / Fifty years after the "Homage to Santa Rosalia": Old and new paradigms on biodiversity in aquatic ecosystems

K. Muylaert $(\bowtie) \cdot$ M. Vanderstukken

Laboratory for Aquatic Biology, K.U.Leuven Campus

Kortrijk, E. Sabbelaan 53, 8500 Kortrijk, Belgium

e-mail: koenraad.muylaert@kuleuven-kortrijk.be

C. Pérez-Martínez · P. Sánchez-Castillo ·

J.-M. Conde-Porcuna

Institute of Water Research, University of Granada,

Ramón y Cajal 4, 18071 Granada, Spain

T. L. Lauridsen · E. Jeppesen

National Environmental Research Institute, Aarhus

University, P.O. Box 314, 8600 Silkeborg, Denmark

\section{S. A. J. Declerck · L. De Meester}

Laboratory for Aquatic Ecology and Evolutionary

Biology, K.U.Leuven, Ch. Deberiotstr. 32, 3000 Leuven,

Belgium variables. Zooplankton:phytoplankton biomass ratios were positively related to submerged macrophyte cover and negatively to phytoplankton generic richness in DK and BNL, suggesting that the low generic richness in lakes with submerged macrophytes was due to a higher zooplankton grazing pressure in these regions. In SP, phytoplankton generic richness was not influenced by zooplankton grazing pressure but related to conductivity. We observed no relationship between phytoplankton generic richness and TP concentration in any of the three regions. The three regions differed significantly with respect to mean local and regional generic richness, with BNL being more diverse than the other two regions. Our observations suggest that phytoplankton diversity in European shallow lakes is

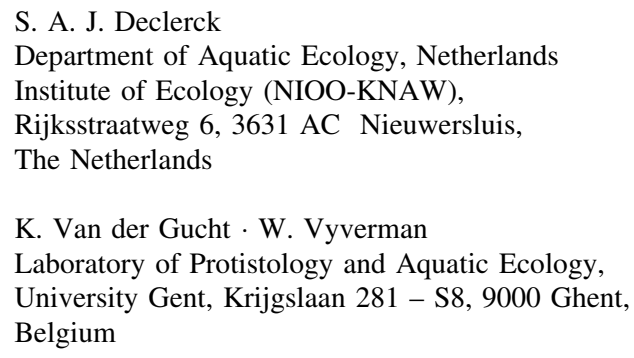


influenced by submerged macrophyte cover indirectly by modulating zooplankton grazing. This influence of submerged macrophytes and zooplankton grazing on phytoplankton diversity decreases from north to south.

Keywords Freshwater biodiversity .

Eutrophication - Submerged macrophytes ·

Latitudinal variation $\cdot$ Zooplankton grazing

\section{Introduction}

In most freshwater ecosystems, the biomass of phytoplankton tends to increase with increasing total phosphorus (TP) concentrations (e.g. Prairie et al., 1989; Basu \& Pick, 1996). In shallow lakes, the relationship between phytoplankton biomass and TP concentrations is influenced by submerged macrophytes. At a given TP level, meso- to eutrophic shallow lakes may have either low or high phytoplankton biomass depending on the presence or absence of well-developed submerged macrophyte vegetation (Scheffer et al., 1993). This is because submerged macrophytes in shallow lakes can form a dense vegetation that controls phytoplankton biomass through several mechanisms, including allelopathic interactions (Gross, 2003), nutrient limitation (Van Donk et al., 1993), shading and providing of a refuge for zooplankton that can control phytoplankton by grazing (Timms \& Moss, 1984; Schriver et al., 1995; Burks et al., 2002). Recent studies indicate that zooplankton body size becomes smaller (Gillooly \& Dodson, 2000) and that the zooplankton:phytoplankton biomass ratio declines from cold to warm lakes, likely due to enhanced fish predation (Lazzaro, 1997; Gyllström et al., 2005; Jeppesen et al., 2007a; Havens et al., 2009), and that the refuge capacity of submerged macrophyte for zooplankton is lower in warm lakes where fish are very abundant in the vegetation (Meerhoff et al., 2007a, b; Teixeira-de Mello et al., 2009).

In many ecosystems, including also aquatic ecosystems, biodiversity is closely related to nutrient concentrations (Hillebrand et al., 2001). For Danish, mainly shallow lakes, Jeppesen et al. (2000) observed a unimodal relationship of phytoplankton diversity to $\mathrm{TP}$, peaking at intermediate to high concentrations (100-400 $\mu \mathrm{g} \mathrm{P}^{-1}$ ) and being low at low TP where macrophytes are abundant. In a study of a set of interconnected shallow lakes in Belgium, Vanormelingen et al. (2008) found no relationship of phytoplankton diversity with nutrient concentrations, but a negative relation with submerged macrophytes cover. Kruk et al. (2009) also found no relationship of phytoplankton diversity to TP in a set of 18 lakes in subtropical Uruguay, but observed a positive relationship to percentage of plant volume infested (PVI, sensu Canfield et al., 1984) of submerged macrophytes. Kruk et al. (2009) hypothesized that the difference in the relation between phytoplankton diversity and submerged macrophytes might be due to the much higher density of submerged macrophytes in tropical lakes, suggesting that macrophytes might have a negative influence on phytoplankton diversity at low macrophyte cover but a positive influence at very high macrophyte cover. It is known that grazing pressure may affect phytoplankton biomass and diversity in shallow lakes (Schriver et al., 1995; Søndergaard \& Moss, 1998) and that submerged macrophytes influence grazing pressure in temperate but much less in tropical shallow lakes (see above). Whether the difference in effects of macrophytes on phytoplankton diversity among the temperate and subtropical lakes can be related to differences in zooplankton grazing pressure remains unresolved.

The goal of this study was to relate TP and submerged macrophytes with phytoplankton biomass and diversity along a European latitudinal gradient, and to evaluate the role of zooplankton grazing on these relationships. We studied phytoplankton biomass and generic richness in 98 shallow lakes from three European regions (Denmark, Belgium/The Netherlands and Spain). In shallow lakes, submerged macrophytes tend to be more common in low TP lakes than in high TP lakes. To allow us to independently assess the effect of TP and submerged macrophytes on phytoplankton diversity, lakes were selected in such a way that submerged macrophyte cover would vary independently from TP concentrations (Declerck et al., 2005). The data collected also permitted us to evaluate whether latitudinal differences in phytoplankton diversity exist in Europe. Although ample literature exists on latitudinal variation in diversity of many groups of organisms (e.g. Rohde, 1992), remarkably few studies have investigated latitudinal variation in diversity of phytoplankton. 


\section{Methods}

Selection and sampling of lakes

Selection and sampling of the shallow lakes for this study were carried out within the framework of the EU project BIOMAN (De Meester et al., 2006). Data in the different regions were collected by different research teams. Rigid working protocols were established and workshops and intercalibration exercises were carried out to standardize the methods and level of expertise. Shallow lakes were defined as lakes with a mean depth $<3 \mathrm{~m}$ and a maximum depth of $5 \mathrm{~m}$. Shallow lakes were sampled in three European regions located at different latitudes: Denmark (DK, $\left.n=32,55^{\circ} 48^{\prime}-56^{\circ} 27^{\prime} \mathrm{N}\right)$, Belgium/The Netherlands (BNL, $n=34,50^{\circ} 48^{\prime}-52^{\circ} 41^{\prime} \mathrm{N}$ ) and southern Spain (SP, $n=32,36^{\circ} 10^{\prime}-39^{\circ} 25^{\prime} \mathrm{N}$ ). Half of the lakes in each region were sampled in 2000 , the other half in 2001. Lakes in the three regions were selected to be as similar as possible with respect to chemical characteristics (salinity, acidity, alkalinity, humic substances, and iron content). The lakes sampled were approximately evenly distributed over four categories defined by two factors: high or low TP content ( $>$ or $<100 \mu \mathrm{g} \mathrm{l}^{-1} \mathrm{TP}$ ) and high or low cover of submerged macrophytes ( $>$ or $<20 \%$ of the lake area surface covered). This sampling strategy allowed us to independently evaluate the effect of phosphorus and submerged macrophytes on phytoplankton generic richness. Cover by submerged macrophytes varied independently of the TP concentration in the regions BNL and SP (Pearson correlation: BNL: $r=-0.09, P=0.624$, SP: $r=-0.27, P=0.122$ ), but was significantly negatively correlated with TP in DK (Pearson correlation: $r=-0.43, P=0.014$ ).

To integrate temporal and spatial variability within each lake, the lakes were sampled repeatedly monthly during 6 months throughout the summer half-year and water was pooled from eight (lakes $<5$ ha) or 16 (lakes $>5$ ha) randomly chosen locations within each lake. At the end of the sampling season, samples from different months were mixed at equal volumes to yield one composite sample that was analysed for phytoplankton diversity. In densely vegetated or very shallow lakes, sampling phytoplankton using traditional samplers like Van Dorn or integrated samplers might lead to inclusion of periphytic and benthic micro-algae in the phytoplankton samples. Therefore, we used a large syringe connected to a flexible silicone tube ( $3 \mathrm{~mm}$ diameter) to collect a subsurface water sample without disturbing the benthos and periphyton. Zooplankton was collected by filtration of 151 through a $64 \mu \mathrm{m}$ mesh. Many Spanish lakes, however, were characterized by very low crustacean zooplankton densities and for this region larger samples were often taken (up to 45 1). Zooplankton was fixed with Lugol's solution (4\%). Samples for both phytoplankton and zooplankton were fixed with acid Lugol's solution and stored in dark.

On each sampling occasion, temperature, conductivity, $\mathrm{pH}$ and Secchi depth were measured at a fixed location in each lake. Suspended particulate matter (SPM) was each month determined gravimetrically by filtering a known volume of water onto a preweighed GF/F filter. Total nitrogen (TN) and TP were measured on pooled monthly samples that were stored frozen. Submerged macrophyte cover was determined when macrophyte biomass was maximal (June in SP, July in BNL and August in DK). Submerged macrophyte cover was determined at a series of points distributed evenly along a set of randomly chosen transects across the lake. The number of transects and the number of points per transect varied with lake size (10 transects of 50 points in lakes $<5$ ha to 20 transects of 150 points in lakes $>20$ ha). Fish were sampled during late summer in the littoral as well as the open water using nylon gill nets with differing mesh sizes. For more detailed descriptions of the sampling protocols we refer to Declerck et al. (2005).

\section{Analysis of samples}

Phytoplankton was identified and enumerated using inverted microscopy. Samples from each region were analysed by a different scientist, but genus lists and identification were thoroughly compared between the scientists involved to avoid bias when comparing diversity between the three regions. In each region, identification was to at least genus level and genus level is therefore used in the analysis. To evaluate the effect of such a reduced taxonomic resolution, identification in DK was carried out to species level as well. We found that generic richness was a good predictor of species richness in DK (linear regression: $n=32, F=715, P<0.001$, Fig. 1) and species richness was on average 16\% higher than generic 


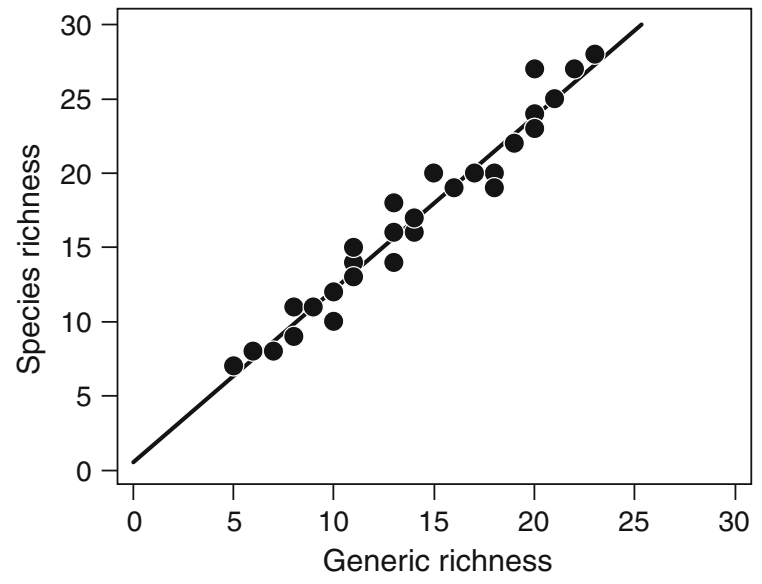

Fig. 1 Relationship between genus richness and species richness in the Denmark (DK) region

richness. We therefore assume that generic richness is a valuable surrogate for species richness. To ensure saturation of the collector's curve and an accurate estimate of generic richness, minimum 200 individuals (cells, colonies or coenobia) were counted and counting was continued until no new genera were found among the last 50 individuals inspected. To estimate the biomass of individual phytoplankton genera, 10 cells or colonies or all cells or colonies (if $<10$ cells or colonies were observed during the count) were measured per sample and biovolume was calculated. Biovolume data were converted to biomass (in C) using published carbon-volume regressions (Menden-Deuer \& Lessard, 2000). Zooplankton was counted and identified to species level with a stereomicroscope. Density estimates of zooplankton populations were converted to dry weight biomass using published length-weight regression relationships.

\section{Data analyses}

ANCOVA analyses were used to relate phytoplankton biomass and generic richness (dependent variables) to environmental variables (continuous predictive variables or covariates) across the three regions while correcting for differences between the regions (categorical predictive variable). Environmental variables tested were submerged macrophyte cover, TP and TN concentrations, conductivity, $\mathrm{pH}$, suspended particulate matter concentrations (SPM), Secchi depth, fish biomass and lake area. To evaluate whether phytoplankton generic richness was influenced by zooplankton grazing pressure, ANCOVA was also used to investigate the influence of submerged macrophytes on zooplankton grazing pressure as well as the influence of this grazing pressure on phytoplankton generic richness. To evaluate the influence of submerged macrophyte cover on zooplankton grazing and the influence of zooplankton grazing on phytoplankton generic richness, the grazing pressure of zooplankton on phytoplankton was estimated from the ratio of zooplankton biomass over phytoplankton biomass (cf. Jeppesen et al., 1994). In the ANCOVA analysis, we were primarily interested in consistent effects of the environmental variables across the three regions. Therefore, homogeneity of slopes test was carried out prior to the ANCOVA analysis to test whether the slope of the relation between an environmental variable and phytoplankton biomass or generic richness was comparable in the three regions. Pearson correlation coefficients were calculated to investigate the relationship between environmental variables and phytoplankton biomass or generic richness within each region. To ensure normal distribution of the data, TP and TN concentration, conductivity, phytoplankton biomass, grazing pressure, SPM, Secchi depth and lake area required $\log _{10}$-transformation, while submerged macrophyte cover required double square-root transformation.

To evaluate whether generic richness differed between the three regions, mean local and regional generic richness were compared. Mean local generic richness was compared between the three regions using one-way ANOVA with Scheffé's post-hoc test. Regional generic richness was defined as the total number of genera found in each region. To evaluate whether a sufficient number of lakes were investigated to determine regional generic richness, a collector's curve was constructed. For 50 randomly chosen lake sequences, the mean cumulative number of genera found was plotted against the number of lakes sampled and a two-parameter hyperbola of the form $S=\frac{S_{\max } \cdot n}{B+n}$ was fitted to the data (Clench, 1979; Colwell \& Coddington, 1994). The regression allowed us to estimate the maximum regional richness $S_{\max }$ (the asymptotic value of $S$ ) and parameter $B$ (the average number of lakes that would need to be sampled to yield half of the maximum regional richness). Student's $t$ statistic was applied to the 
standard errors of the regression coefficients to test for significant differences in $S_{\max }$ and $B$ between the regions.

\section{Results}

ANCOVA analyses indicated that phytoplankton biomass was significantly positively related to TP and negatively to submerged macrophytes (Fig. 2; Table 1). Homogeneity of slopes tests and Pearson correlation coefficients indicated that the relation of phytoplankton biomass with submerged macrophyte cover was consistent across the three regions. The positive relation with $\mathrm{TP}$ was consistent across the three regions, but was only significant in BNL and SP according to Pearson correlation coefficients. Phytoplankton biomass was also significantly positively related to SPM and negatively to Secchi depth in each region (Table 1). Pearson correlation coefficients indicated that phytoplankton biomass was positively related to TN and fish biomass in BNL. There was no significant relation with conductivity, lake area or $\mathrm{pH}$.

A total of 106 phytoplankton genera were encountered in the lakes from the three regions (Table 2). A higher number of genera was found in BNL (85 taxa) than in DK (66 taxa) and SP (63 taxa). In the three regions, the collector's curve fitted well to a two-parameter hyperbola (Fig. 3; Table 3). The
Fig. 2 Relationship between phytoplankton

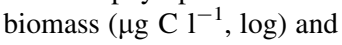
submerged macrophyte cover $(\%$, double square root), total phosphorus concentration $\left(\mu \mathrm{g} \mathrm{l}^{-1}, \log \right)$, total nitrogen concentration $\left(\mathrm{mg} \mathrm{l}^{-1}, \log \right)$ and conductivity $\left(\mathrm{mS} \mathrm{cm}{ }^{-1}\right.$, $\log$ ) in the regions Denmark (DK), Belgium/The Netherlands (BNL) and Spain (SP)
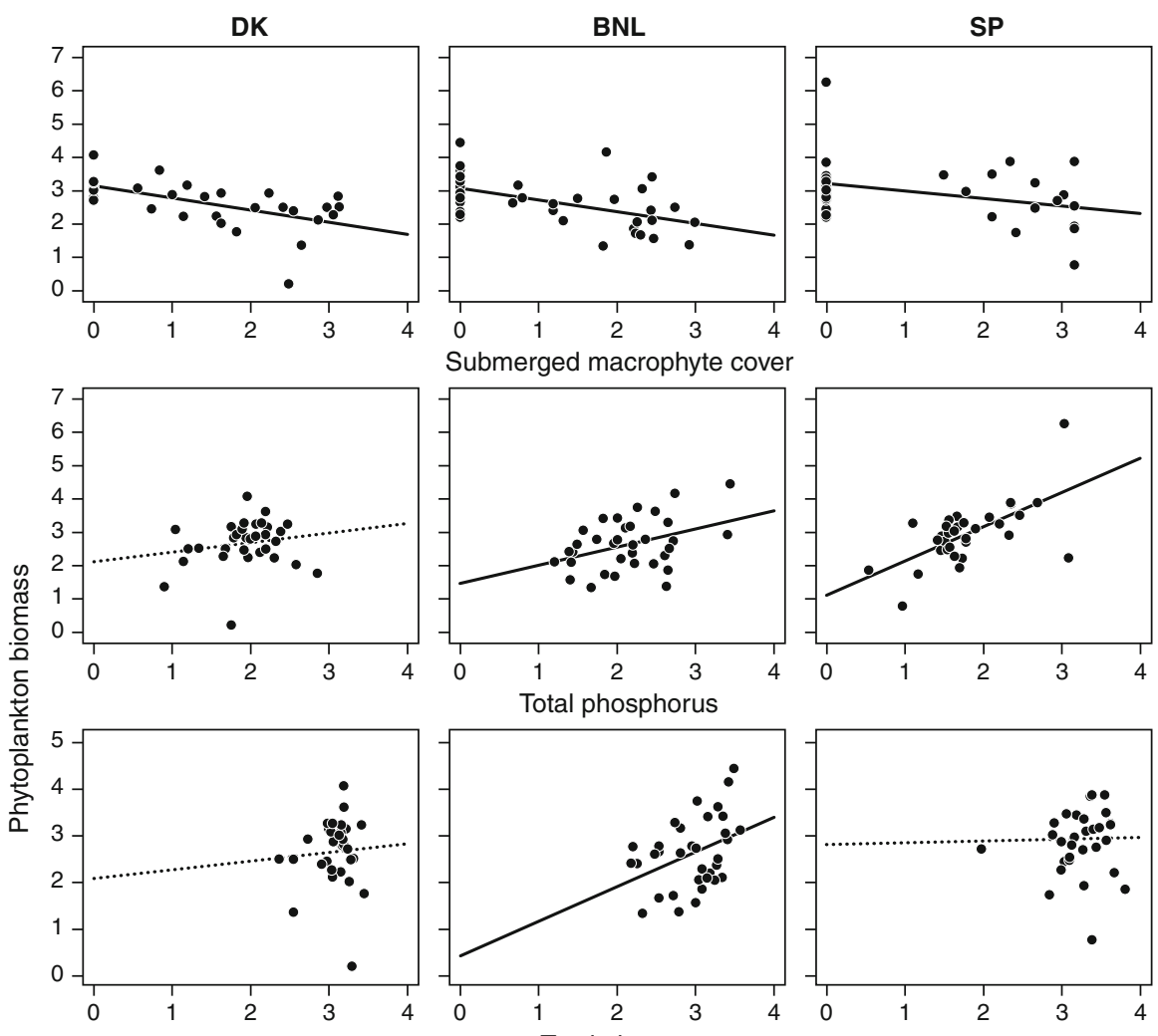

Submerged macrophyte cover
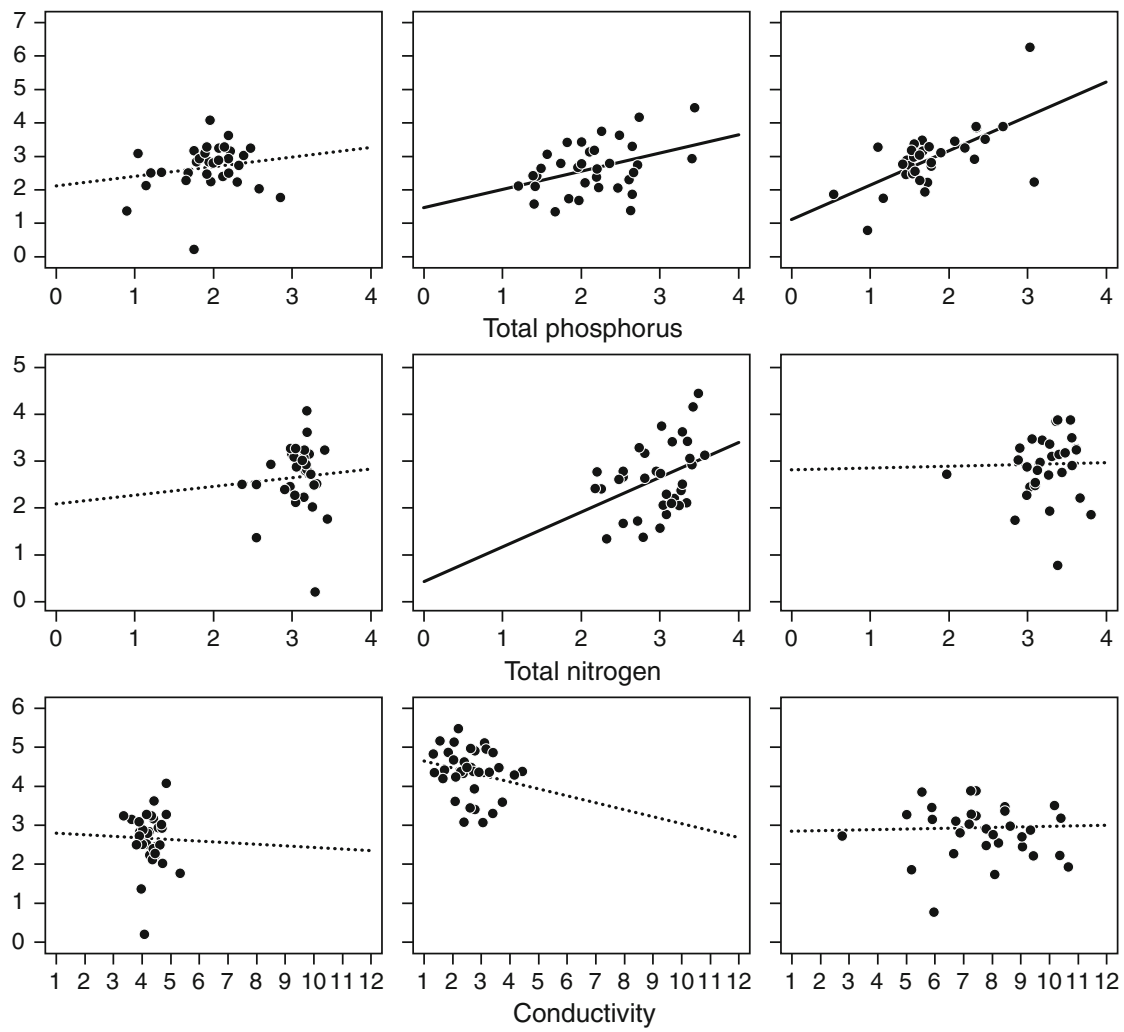
Table 1 Results of ANCOVA, homogeneity of slopes (Hom. slopes) and Pearson correlation analyses evaluating the relationship between phytoplankton biomass and generic richness and environmental variables across the three regions studied

\begin{tabular}{|c|c|c|c|c|c|c|c|}
\hline \multicolumn{4}{|l|}{ ANCOVA } & \multirow{2}{*}{$\begin{array}{l}\text { Hom. slopes } \\
P \text { level }\end{array}$} & \multicolumn{3}{|c|}{ Pearson correlation } \\
\hline Dependent variable & Covariable & $F$-value & $P$ level & & DK & BNL & SP \\
\hline Biomass & Subm. macrophytes & 21.29 & $<0.001$ & 0.455 & -0.59 & -0.51 & -0.34 \\
\hline Biomass & Total phosphorus & 21.89 & $<0.001$ & 0.091 & 0.18 & 0.40 & 0.63 \\
\hline Biomass & Total nitrogen & 0.13 & 0.718 & 0.024 & -0.05 & 0.47 & -0.12 \\
\hline Biomass & Conductivity & 0.56 & 0.456 & 0.649 & -0.03 & -0.21 & 0.05 \\
\hline Biomass & $\mathrm{pH}$ & 2.15 & 0.145 & 0.187 & 0.13 & -0.10 & 0.34 \\
\hline Biomass & Secchi & 67.75 & $<0.001$ & 0.231 & -0.38 & -0.72 & -0.74 \\
\hline Biomass & SPM & 67.28 & $<0.001$ & 0.251 & $\underline{0.47}$ & 0.64 & 0.76 \\
\hline Biomass & Fish biomass & 3.22 & 0.076 & 0.070 & 0.09 & 0.59 & -0.09 \\
\hline Biomass & Lake area & 0.70 & 0.403 & 0.322 & 0.10 & -0.07 & 0.25 \\
\hline Generic richness & Subm. macrophytes & 16.41 & $<0.001$ & 0.533 & -0.55 & -0.37 & -0.35 \\
\hline Generic richness & Total phosphorus & 1.88 & 0.173 & 0.163 & -0.03 & 0.30 & 0.14 \\
\hline Generic richness & Total nitrogen & 0.19 & 0.659 & 0.378 & 0.00 & 0.15 & 0.21 \\
\hline Generic richness & Conductivity & 0.00 & 0.996 & 0.052 & -0.12 & 0.19 & -0.32 \\
\hline Generic richness & $\mathrm{pH}$ & 0.16 & 0.690 & 0.273 & 0.32 & 0.09 & -0.15 \\
\hline Generic richness & Secchi & 11.97 & $<0.001$ & 0.093 & -0.40 & -0.43 & -0.31 \\
\hline Generic richness & SPM & 13.70 & $<0.001$ & 0.012 & 0.55 & $\underline{0.49}$ & 0.25 \\
\hline Generic richness & Fish biomass & 10.44 & 0.002 & 0.070 & $\underline{0.38}$ & $\underline{0.48}$ & -0.07 \\
\hline Generic richness & Lake area & 5.55 & 0.020 & 0.368 & 0.43 & 0.27 & -0.01 \\
\hline
\end{tabular}

For the Pearson correlation coefficients, bold correspond to $P$-value $<0.05$, single underlined to $P$-value $<0.01$ and italics to $P$-value $<0.001$

estimated maximum regional generic richness was significantly higher in BNL than in DK and SP. Estimated maximum regional generic richness was also significantly higher in DK than in SP, but the difference was very small ( 5 taxa). The number of genera encountered per lake varied between 5 and 45 . Mean generic richness per lake was significantly higher in BNL (24.6 genera) than in DK (14.1 taxa) and SP (15.4 taxa) and did not differ between DK and SP (ANOVA $P<0.001$, Scheffé's post-hoc test: $\mathrm{BNL}>\mathrm{DK}=\mathrm{SP})$.

ANCOVA analyses indicated that generic richness was significantly negatively related to submerged macrophytes but not to TP (Fig. 4; Table 1). The homogeneity of slopes test and Pearson correlation coefficients showed that the negative relationship with submerged macrophytes was significant in all regions. Pearson correlation coefficients did indicate a positive relationship with TP concentrations in BNL. Phytoplankton taxon richness was also significantly negatively related to Secchi depth and positively to SPM and fish biomass in DK and BNL
(Table 1). We also observed a positive relation of phytoplankton diversity with lake area and $\mathrm{pH}$ in $\mathrm{DK}$ and a negative relation with conductivity in SP.

According to ANCOVA analyses, the estimated zooplankton grazing pressure was significantly positively related to submerged macrophyte cover, while phytoplankton generic richness was negatively related to zooplankton grazing pressure (Fig. 5; Table 4). Pearson correlation coefficients indicated that these relationships were significant in DK and BNL, but not in SP.

\section{Discussion}

The number of phytoplankton genera found per lake differed significantly between the three regions and was higher in BNL than in the DK and SP regions. The total number of genera found in a region was also higher in BNL than DK and SP. These differences in regional and mean local generic richness were quite large and equalled variation in local generic richness 
Table 2 Overview of taxa found in at least 10 lakes during this study

\begin{tabular}{|c|c|c|c|}
\hline & DK & BNL & $\mathrm{SP}$ \\
\hline Number of lakes & 32 & 34 & 32 \\
\hline \multicolumn{4}{|l|}{ Cyanobacteria } \\
\hline Anabaena/Anabaenopsis & 34 & 53 & 53 \\
\hline Aphanizomenon & 19 & 24 & - \\
\hline Aphanothece & 9 & 9 & 25 \\
\hline Merismopedia & - & 38 & 50 \\
\hline Microcystis & 28 & 18 & 67 \\
\hline Oscillatoria & 47 & 12 & 59 \\
\hline Planktothrix & 13 & 18 & - \\
\hline Pseudanabaena & - & 18 & 63 \\
\hline \multicolumn{4}{|l|}{ Euglenophyta } \\
\hline Euglena & 3 & 35 & 44 \\
\hline Lepocinclis & 3 & 29 & 13 \\
\hline Phacus & 19 & 53 & 19 \\
\hline Trachelomonas & 19 & 62 & 13 \\
\hline \multicolumn{4}{|l|}{ Dinophyta } \\
\hline Ceratium & 6 & 21 & 6 \\
\hline Gymnodinium & 13 & 29 & 19 \\
\hline Peridinium/Peridiniopsis & 22 & 29 & 44 \\
\hline \multicolumn{4}{|l|}{ Cryptophyta } \\
\hline Cryptomonas & 91 & 100 & 78 \\
\hline Rhodomonas/Chroomonas & 100 & 100 & 72 \\
\hline \multicolumn{4}{|l|}{ Chlorophyta } \\
\hline Actinastrum & 9 & 29 & 9 \\
\hline Ankyra & 34 & 32 & 19 \\
\hline Chlorogonium & 3 & 13 & 31 \\
\hline Closteriopsis & 3 & 6 & 28 \\
\hline Closterium & 25 & 65 & 13 \\
\hline Coelastrum & 19 & 62 & 19 \\
\hline Cosmarium & - & 24 & 22 \\
\hline Crucigenia & 6 & 29 & 19 \\
\hline Crucigeniella & 13 & 41 & - \\
\hline Dictyosphaerium & 25 & 41 & 31 \\
\hline Eutetramorus & - & 38 & 3 \\
\hline Golenkinia & - & 32 & 9 \\
\hline Kirchneriella/Nephrochlamys & 3 & 62 & - \\
\hline Lagerheimia/Chodatella & 16 & 18 & 16 \\
\hline Monoraphidium/Koliella/Korschikoviella & 78 & 77 & 66 \\
\hline Oocystis & 13 & 65 & 72 \\
\hline Pediastrum & 31 & 59 & 6 \\
\hline Planktosphaeria & - & 38 & 9 \\
\hline Quadrigula & - & 32 & - \\
\hline Scenedesmus & 44 & 94 & 69 \\
\hline Schroederia & - & 29 & - \\
\hline
\end{tabular}

Table 2 continued

\begin{tabular}{|c|c|c|c|}
\hline & $\mathrm{DK}$ & $\mathrm{BNL}$ & SP \\
\hline Sphaerocystis & 25 & - & 9 \\
\hline Staurastrum & 3 & 26 & 3 \\
\hline Tetraedron & 25 & 56 & 34 \\
\hline Tetrastrum & 28 & 47 & - \\
\hline \multicolumn{4}{|l|}{ Chrysophyta_Chrysophyceae } \\
\hline Dinobryon & 41 & 29 & 6 \\
\hline Mallomonas & 22 & 65 & 3 \\
\hline \multicolumn{4}{|l|}{ Chrysophyta-Bacillariophyceae } \\
\hline Asterionella & 47 & 32 & 3 \\
\hline Aulacoseira & 44 & 35 & 3 \\
\hline Cyclotella & 19 & 24 & 59 \\
\hline Fragilaria/Synedra & 53 & 6 & 44 \\
\hline Nitzschia & 44 & 21 & 53 \\
\hline Stephanodiscus & 63 & 71 & 3 \\
\hline \multicolumn{4}{|l|}{ Incertae Sedis } \\
\hline Unidentified coccoid cells & 6 & 62 & 19 \\
\hline Unidentified nanoflagellates & 97 & 71 & 84 \\
\hline
\end{tabular}

For each region, the percentage of lakes in which the genus was found is given

within each region. Because samples from each region were analysed by different scientists, this may potentially be the result of analysis biases. However, this seems unlikely because identification was at the genus level and is therefore not expected to be influenced by the level of expertise of the scientist. Moreover, species lists and identifications were carefully compared between the scientists. The lower diversity in the DK region might therefore be related to a shorter growing season at higher latitudes. In benthic diatom assemblages in polar lakes, diversity increases with the length of the growing season because more complex assemblages develop during long growing seasons (Smol, 1988; Michelutti et al., 2002). In the SP region, the low diversity may be due to the higher conductivity, which may result in osmotic stress. It is well-known that osmotic stress may cause a decline in phytoplankton diversity in lakes with high conductivity (e.g. Williams, 1998; Padisák et al., 2003). Alternatively, long periods with high temperatures may lead to stable environmental conditions, which results in a decrease in diversity due to competitive exclusion of most taxa from the community (Sommer et al., 1993; Naselli-Flores et al., 2003; Becker et al., 2008). These latitudinal 


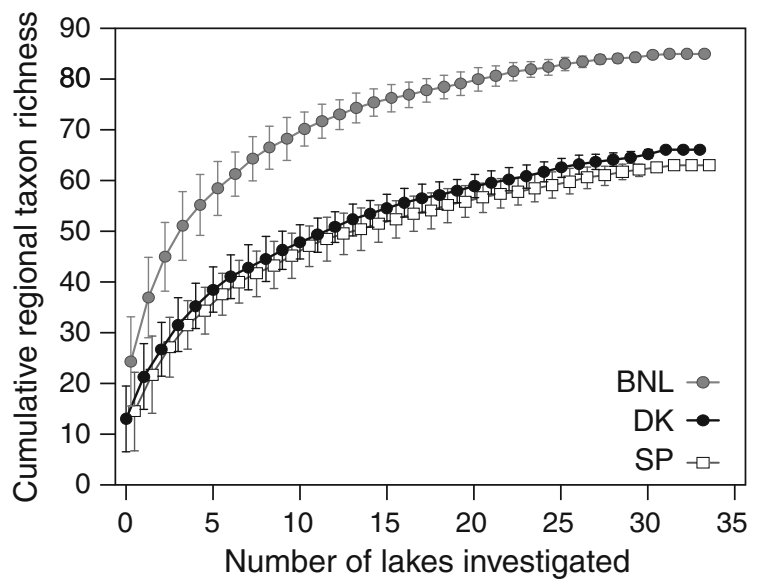

Fig. 3 Cumulative regional generic richness plotted against the number of lakes investigated. The series displayed is the mean for 50 random lake sequences; error bars indicate the standard deviation around the mean

Table 3 Results of hyperbolic regression of the cumulative number of taxa found in each region $(S)$ versus the number of lakes sampled in that region $(n): S=\frac{S_{\max } \cdot n}{B+n}$

\begin{tabular}{|c|c|c|c|}
\hline & DK & $\mathrm{BNL}$ & SP \\
\hline \multicolumn{4}{|l|}{ Parameter $S_{\max }$} \\
\hline Value & 77 & 93 & 72 \\
\hline $95 \%$ confidence & 1.5 & 0.9 & 1.7 \\
\hline$P$-level & $<0.0001$ & $<0.0001$ & $<0.0001$ \\
\hline \multicolumn{4}{|l|}{ Parameter B } \\
\hline Value & 6.1 & 3.4 & 5.6 \\
\hline $95 \%$ confidence & 0.41 & 0.16 & 0.5 \\
\hline$P$-level & $<0.0001$ & $<0.0001$ & $<0.0001$ \\
\hline$r^{2}$ & 0.993 & 0.995 & 0.987 \\
\hline
\end{tabular}

For each regression, parameters $S_{\max }$ and $B$ are given together with their $95 \%$ confidence interval. The $r^{2}$ value for the regression model is given for each region

differences in generic richness and the underlying factors require further investigation.

Phytoplankton biomass was negatively related to submerged macrophyte cover across the three regions and positively to TP concentrations in BNL and SP. Phytoplankton biomass was related to other environmental parameters that are related to submerged macrophytes cover (Secchi depth, SPM, fish biomass) or nutrient loading (TN concentration). This is in agreement with many previous studies indicating that both macrophytes and nutrients affect phytoplankton biomass in shallow lakes (Scheffer et al., 1993). The correlation of phytoplankton biomass with submerged macrophytes was strongest in the northernmost region and weakest in the southernmost region, suggesting an effect of latitudinal position on the relationship between submerged macrophytes and phytoplankton biomass. This concords with the recent findings that the effect of submerged macrophytes on phytoplankton is weaker in subtropical than in temperate shallow lakes (Bachmann et al., 2002; Jeppesen et al., 2007b; Meerhoff et al., 2007a, b).

Generic richness was negatively related to submerged macrophyte cover and environmental factors closely related to submerged macrophyte cover (Secchi depth, SPM, fish biomass) across the three regions. Submerged macrophytes in shallow lakes suppress phytoplankton through several direct and indirect mechanisms, and these pressures on phytoplankton may not only influence phytoplankton biomass but also limit the number of taxa in the community. Among other factors, the high grazing pressure in lakes with a high submerged macrophyte cover may result in a decrease in phytoplankton diversity. According to a meta-analysis of herbivore effects on primary producers across different ecosystems, herbivores generally cause a reduction in primary producer diversity in aquatic ecosystems (Hillebrand et al., 2001). This is ascribed to the large body-size ratios between grazers and primary producers in aquatic systems, which results in a low selectivity of the herbivores to their prey. In shallow lakes with submerged macrophytes, large zooplankton, like Daphnia, feed on a wide size range of phytoplankton (Hall et al., 1976) and can exert a strong grazing pressure on phytoplankton (Schriver et al., 1995). They can reduce diversity by causing a shift towards small fast growing cells or large cells that are too big to ingest, both groups representing a reduced spectrum of species. A high grazing pressure is known to result in lower phytoplankton diversity (Padisák, 1993; Krasznai et al., 2010). In a mesocosm experiment investigating the influence of submerged macrophytes on phytoplankton diversity, submerged macrophytes had a positive influence on diversity (Declerck et al., 2007). In that experiment, zooplankton grazing pressure did not differ significantly between treatments with and without macrophytes due to the absence of fish (Vanderstukken et al., 2010). However, in a similar experiment where the influence of Daphnia was isolated that of submerged macrophytes, Daphnia was found to reduce diversity 
Fig. 4 Relationship between phytoplankton generic richness and submerged macrophyte cover (\%, double square root), total phosphorus concentration $\left(\mu \mathrm{g} \mathrm{l}^{-1}, \log \right)$, total nitrogen concentration $\left(\mathrm{mg}^{-1}, \log \right)$ and conductivity $\left(\mathrm{mS} \mathrm{cm} \mathrm{cm}^{-1}\right.$, $\log$ ) in the regions Denmark (DK), Belgium/The Netherlands (BNL) and Spain (SP)
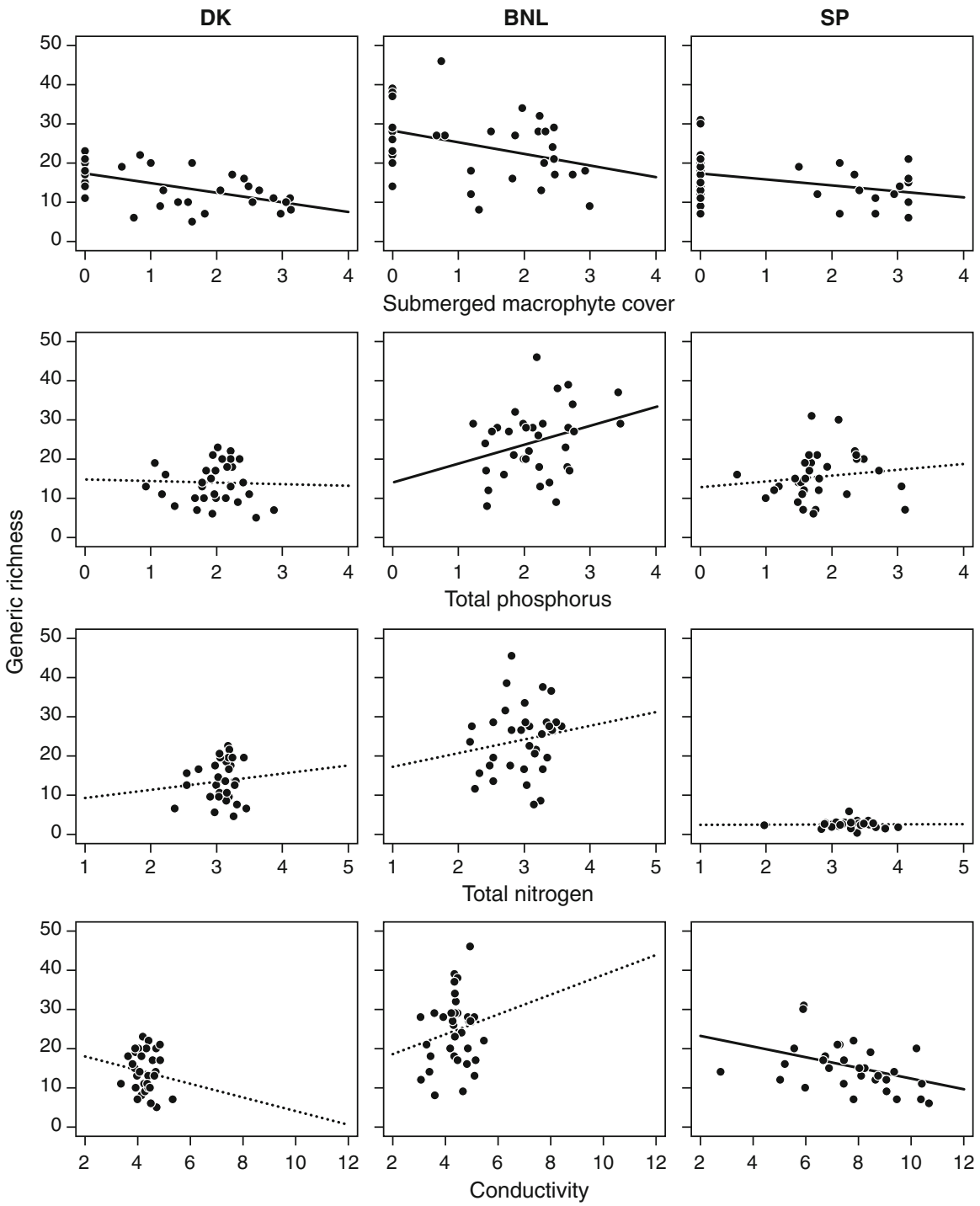

by inducing a shift in the community towards almost complete dominance by cryptophytes (Vanderstukken et al., submitted). We estimated the grazing pressure of zooplankton on phytoplankton using the zooplankton:phytoplankton biomass ratio. In DK and BNL, the zooplankton:phytoplankton biomass ratio was indeed positively related to submerged macrophyte cover, and generic richness decreased at higher zooplankton: phytoplankton biomass ratios.

The negative relationship between generic richness and submerged macrophyte cover is in contrast with observations in South American shallow lakes, where a positive relationship was observed (Kruk et al., 2009). This discrepancy may be due to the fact that large grazers like Daphnia are rare in subtropical lakes (Gillooly \& Dodson, 2000; Havens et al., 2009), likely due to high predation from fish. The influence of herbivores on the plankton community is, consequently, weaker in subtropical lakes (Jeppesen et al., 2007b, 2010; Meerhoff et al., 2007a, b, Havens et al., 2009). This lower importance of large grazers in warm climates may also explain why the relationship between macrophytes and phytoplankton generic richness in our study was the weakest in the southern-most region (SP). Moreover, in SP, no significant relationship was observed between the zooplankton:phytoplankton biomass ratio and submerged macrophyte cover or between generic richness and the zooplankton:phytoplankton biomass ratio. Daphnia abundance was also significantly 
Fig. 5 Relationship between zooplankton grazing pressure (ratio, log) and submerged macrophyte cover $(\%$, double square root) and between phytoplankton generic richness and grazing pressure (ratio, log) in the regions Denmark (DK), Belgium/The Netherlands (BNL) and Spain (SP)
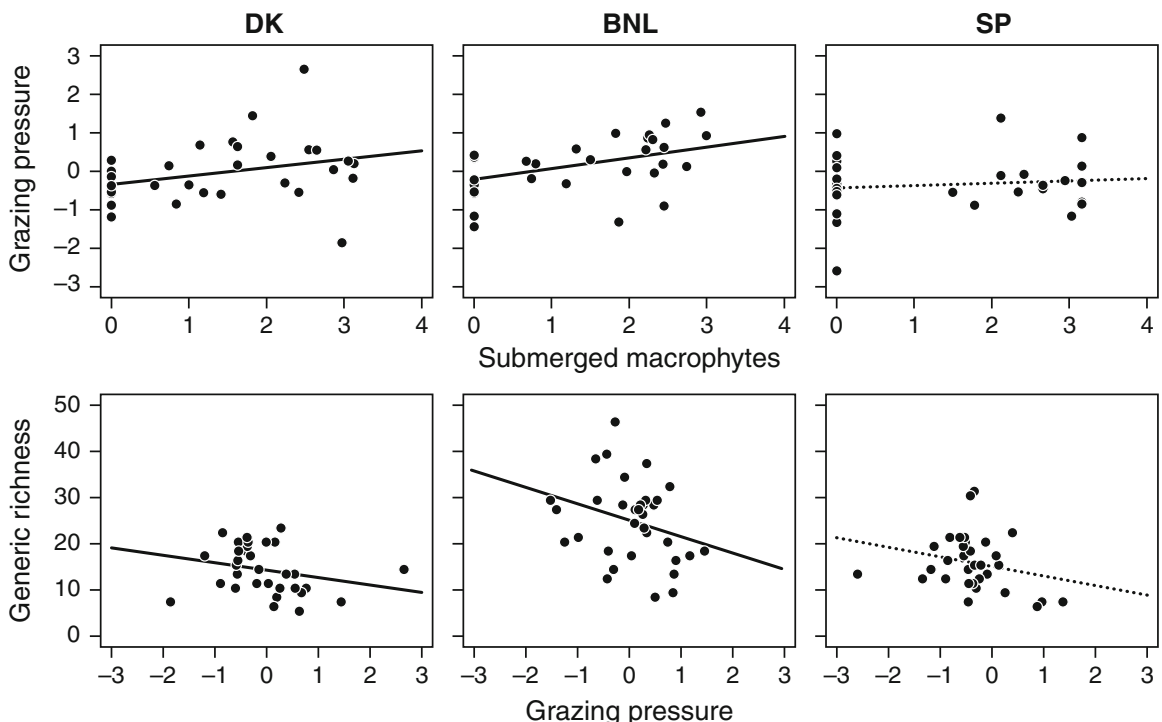

Table 4 Results of ANCOVA and Pearson correlation analyses evaluating the relationship between zooplankton grazing pressure and submerged macrophyte cover and between phytoplankton generic richness and zooplankton grazing across the three regions studied

\begin{tabular}{|c|c|c|c|c|c|c|}
\hline \multicolumn{4}{|l|}{ ANCOVA } & \multicolumn{3}{|c|}{ Pearson correlation } \\
\hline Dependent variable & Independent variable & $F$-value & $P$ level & DK & $\mathrm{BNL}$ & SP \\
\hline Grazing pressure & Subm. macrophytes & 8.59 & 0.004 & 0.31 & $\underline{0.43}$ & 0.12 \\
\hline Generic richness & Grazing pressure & 7.26 & 0.008 & -0.31 & -0.28 & -0.24 \\
\hline
\end{tabular}

For the Pearson correlation coefficients, bold corresponds to $P$-value $<0.05$, single underlined to $P$-value $<0.01$

lower in SP than in the other two regions (ANOVA: $F=6.41, P=0.002)$. In SP, conductivity appeared to have an influence on phytoplankton generic richness (see above). Due to the carbonate- and sulphate-rich watersheds of the lakes in SP, conductivity was in general high in the SP lakes.

Despite the influence of TP on phytoplankton biomass, generic richness was not significantly related to TP concentrations. This is in contrast with studies from other aquatic ecosystems, where diversity is often found to be positively related to TP concentrations (Hillebrand et al., 2001). This suggests that in shallow lakes submerged macrophytes exert a stronger influence on phytoplankton diversity than TP. TP, however, may indirectly influence phytoplankton diversity in shallow lakes because the probability of having a vegetated state decreases with increasing TP concentration (e.g. Moss, 1990; Scheffer et al., 1993; Janse, 1997). This may indirectly lead to a positive relationship between TP concentrations and phytoplankton diversity. In our study, however, lakes were selected such that the TP concentration varied independently from submerged macrophyte cover. In a set of 76 Danish randomly selected shallow lakes, Jeppesen et al. (2000) observed an increase in phytoplankton diversity with TP concentration over a comparable range of TP concentrations as covered in our study. Possibly, the increase in diversity with TP observed by Jeppesen et al. (2000) was in part explained by a concomitant decrease in submerged macrophyte cover.

In conclusion, our results revealed a negative effect of submerged macrophytes on phytoplankton generic richness in shallow lakes from three European regions, but no direct effect of nutrients. At least in the two regions at higher latitudes, the relation between generic richness and zooplankton:phytoplankton biomass ratios suggests that the negative influence of submerged macrophytes on generic richness may be mediated by herbivory in the presence of macrophytes. The negative effect of macrophytes on phytoplankton contrasts with the positive effect of macrophytes on 
other organisms (Declerck et al., 2005; De Meester et al., 2006). Our results also suggest that similar lakes at different latitudes may differ substantially in regional and mean local phytoplankton generic richness.

Acknowledgements The research presented in this paper was carried out within the framework of the EU-project 'BIOMAN: Biodiversity and Human Impact in European Shallow Lakes' (EVK2-CT-1999-00046) and the EU-project EUROLIMPACS (GOCE-CT-2003-505540). Lissa Skov Hansen, Jane StougaardPedersen, Karina Jensen, Jon Svendsen and Kirsten Thomsen (in DK), Jochen Vandekerkhove, Jeroen Van Wichelen and Erik Van Hannen (in BNL) and J.M. Medina-Sánchez, J.A. DelgadoMolina, F. Bullejos, J. López-Ramos and L. Serrano (in SP) assisted in the sampling. Vanessa Geenens, Leni Demarest and Birte Laustsen assisted with sample analyses. We thank all lake owners and managers for allowing us access to the lakes. EJ and TL were also supported by the Danish Natural Science Research Council (272-08-0406), CLEAR and the STF project CRES as well as EU-RFRRESH and EU-WISER. JMCP and CPM were also supported by a research project of the Spanish Ministry of Science and Technology (REN2001-2840/HID).

Open Access This article is distributed under the terms of the Creative Commons Attribution Noncommercial License which permits any noncommercial use, distribution, and reproduction in any medium, provided the original author(s) and source are credited.

\section{References}

Bachmann, R. W., C. A. Horsburgh, M. V. Hoyer, L. K. Mataraza \& D. E. Canfield Jr., 2002. Relations between trophic state indicators and plant biomass in Florida lakes. Hydrobiologia 470: 219-234.

Basu, B. K. \& F. R. Pick, 1996. Factors regulating phytoplankton and zooplankton biomass in temperate rivers. Limnology and Oceanography 41: 1572-1577.

Becker, V., V. L. M. Huszar, L. Naselli-Flores \& J. Padisák, 2008. Phytoplankton equilibrium phases during thermal stratification in a deep subtropical water supply reservoir. Freshwater Biology 53: 952-963.

Burks, R. L., D. M. Lodge, E. Jeppesen \& T. Lauridsen, 2002. Diel horizontal migration of zooplankton: costs and benefits of inhabiting littoral zones. Freshwater Biology 47: 343-365.

Canfield, D. E. Jr, J. V. Shireman, D. E. Colle, W. T. Haller, C. E. I. I. Watkins \& M. J. Maceina, 1984. Prediction of chlorophyll $a$ concentrations in Florida Lakes: importance of aquatic macrophytes. Canadian Journal of Fisheries and Aquatic Sciences 41: 497-501.

Clench, H. K., 1979. How to make regional lists of butterflies: some thoughts. Journal of the Lepidopteran Society 33: 216-231.

Colwell, R. K. \& J. A. Coddington, 1994. Estimating terrestrial biodiversity through extrapolation. Philosophical Transactions of the Royal Society B 345: 101-118.
De Meester, L., S. Declerck, J. Janse, P. J. T. M. Van Puijenbroek, R. Portielje, E. Lammens, E. Jeppesen, T. Lauridsen, K. Schwenk, K. Moylaert, K. Van der Gucht, W. Vyverman, G. Zwart, E. Van Hannen, J. M. CondePorcuna, J. Vandekerkhove \& L. Brendonck, 2006. Chapter 8: Biodiversity in European Shallow Lakes: A Multilevel-Multifactorial Field Study. Ecological Studies. Springer Verlag, New York: 149-167.

Declerck, S., J. Vandekerkhove, L. Johansson, K. Muylaert, J.-M. Conde-Porcuna, K. Van, C. der Gucht, T. Pérez-Martínez, K. Lauridsen, G. Schwenk, W. Zwart, J. Rommens, E. LópezRamos, W. Jeppesen, L. Vyverman, L. Brendonck \& De Meester, 2005. Multi-group biodiversity in shallow lakes along gradients of phosphorus and water plant cover. Ecology 86: 1905-1915.

Declerck, S., M. Vanderstukken, A. Pals, K. Muylaert \& L. De Meester, 2007. Plankton biodiversity along a gradient of productivity and its mediation by macrophytes. Ecology 88: 2199-2210.

Gillooly, J. S. \& S. I. Dodson, 2000. Latitudinal patterns in the size distribution and seasonal dynamics of new world, freshwater cladocerans. Limnology and Oceanography 45: 22-30.

Gross, E. M., 2003. Allelopathy of aquatic autotrophs. Critical Reviews in Plant Sciences 22: 313-339.

Gyllström, M., L.-A. Hansson, E. Jeppesen, F. Garcia-Criado, E. Gross, K. Irvine, T. Kairesalo, R. Kornijów, M. Miracle, M. Nykänen, T. Nõges, S. Romo, D. Stephen, E. Van Donk \& B. Moss, 2005. The role of climate in shaping zooplankton communities of shallow lakes. Limnology and Oceanography 50: 2008-2021.

Hall, D. J., S. T. Threlkeld, C. W. Burns \& P. H. Crowley, 1976. Size-efficiency hypothesis and size structure of zooplankton communities. Annual Review of Ecology and Systematics 7: 177-208.

Havens, K. E., A. C. Elia, M. I. Taticchi \& R. S. Fulton III, 2009. Zooplankton-phytoplankton relationships in shallow subtropical versus temperate lakes Apopka (Florida, USA) and Trasimeno (Umbria, Italy). Hydrobiologia 628: 165-175.

Hillebrand, H., F. Watermann, R. Karez \& U. G. Berninger, 2001. Differences in species richness patterns between unicellular and multicellular organisms. Oecologia 126: 114-124.

Janse, J. H., 1997. A model of nutrient dynamics in shallow lakes in relation to multiple stable states. Hydrobiologia 342: 1-8.

Jeppesen, E., M. Søndergaard, E. Kanstrup, B. Petersen, R. B. Eriksen, M. Hammerhøj, M. Mortensen, J. P. Jensen \& A. Have, 1994. Does the impact of nutrients on the biological structure and function of freshwater and brackish lakes differ? Hydrobiologia 275(276): 15-30.

Jeppesen, E., J. P. Jensen, M. Søndergaard, T. Lauridsen \& F. Landkildehus, 2000. Trophic structure, species richness and biodiversity in Danish lakes: changes along a phosphorus gradient. Freshwater Biology 45: 201-218.

Jeppesen, E., M. Meerhoff, B. A. Jacobsen, R. S. Hansen, M. Søndergaard, J. P. Jensen, T. L. Lauridsen, N. Mazzeo \& C. W. Branco, 2007a. Restoration of shallow lakes by nutrient control and biomanipulation - the successful strategy varies with lake size and climate. Hydrobiologia 581: 269-285. 
Jeppesen, E., M. Søndergaard, M. Meerhoff, T. L. Lauridsen \& J. P. Jensen, 2007b. Shallow lake restoration by nutrient loading reduction - some recent findings and challenges ahead. Hydrobiologia 584: 239-252.

Jeppesen, E., M. Meerhoff, K. Holmgren, I. GonzálezBergonzoni, F. Teixeira-de Mello, S. A. J. Declerck, L. De Meester, M. Søndergaard, T. L. Lauridsen, R. Bjerring, J. M. Conde-Porcuna, N. Mazzeo, C. Iglesias, M. Reizenstein, H. J. Malmquist, Z. W. Liu, D. Balayla \& X. Lazzaro, 2010. Impacts of climate warming on lake fish community structure and dynamics, and potential ecosystem effects. Hydrobiologia 646: 73-90.

Krasznai, E., G. Borics, G. Várbíró, A. Abonyi, J. Padisák, C. Deák \& B. Tóthmérész, 2010. Characteristics of the pelagic phytoplankton in shallow oxbows. Hydrobiologia 639: 173-184.

Kruk, C., L. Rodríguez-Gallego, M. Meerhoff, F. Quintans, G. Lacerot, N. Mazzeo, F. Scasso, J. C. Paggi, E. H. M. Peeters \& M. Scheffer, 2009. Determinants of biodiversity in subtropical shallow lakes (Atlantic coast, Uruguay). Frehwater Biology 54: 2628-2641.

Lazzaro, X., 1997. Do the trophic cascade hypothesis and classical biomanipulation approaches apply to tropical lakes and reservoirs? Verhandlungen der Internationale Vereinigung für Limnologie 26: 719-730.

Meerhoff, M., J. M. Clemente, F. Teixeira-de Mello, C. Iglesias, A. R. Pedersen \& E. Jeppesen, 2007a. Can warm climate-related structure of littoral predator assemblies weaken the clear water state in shallow lakes? Global Change Biology 13: 1888-1897.

Meerhoff, M., C. Iglesias, F. Teixeira-de Mello, J. M. Clemente, E. Jensen, T. L. Lauridsen \& E. Jeppesen, 2007b. Effects of contrasting climates and habitat complexity on community structure and predator avoidance behaviour of zooplankton in the shallow lake littoral. Freshwater Biology 52: 1009-1021.

Menden-Deuer, S. \& E. J. Lessard, 2000. Carbon to volume relationships for dinoflagellates, diatoms, and other protist plankton. Limnology and Oceanography 45: 569-579.

Michelutti, N., A. J. Holtham, M. S. V. Douglas \& J. P. Smol, 2002. Periphytic diatom assemblages from ultra-oligotrophic and UV transparent lakes and ponds on Victoria Island and comparisons with other diatom surveys in the Canadian Arctic. Journal of Phycology 39: 465-480.

Moss, B., 1990. Engineering and biological approaches to the restoration from eutrophication of shallow lakes in which aquatic plant communities are important components. Hydrobiologia 200/201: 367-377.

Naselli-Flores, L., J. Padisák, M. T. Dokulil \& I. Chorus, 2003. Equilibrium/steady-state concept in phytoplankton ecology. Hydrobiologia 502: 395-403.

Padisák, J., 1993. The influence of different disturbance frequencies on the species richness, diversity and equitability of phytoplankton in shallow lakes. Hydrobiologia 249: 135-156.

Padisák, J., G. Borics, G. Fehér, I. Grigorszky, I. Oldal, A. Schmidt \& Z. Zámbóné-Doma, 2003. Dominant species and frequency of equilibrium phases in late summer phytoplankton assemblages in Hungarian small shallow lakes. Hydrobiologia 502: 157-168.

Prairie, Y. T., C. M. Duarte \& J. Kalff, 1989. Unifying nutrient chlorophyll relationships in lakes. Canadian Journal of Fisheries and Aquatic Sciences 46: 1176-1182.

Rohde, K., 1992. Latitudinal gradients in species-diversity the search for the primary cause. Oikos 65: 514-527.

Scheffer, M., S. H. Hosper, M. L. Meijer, B. Moss \& E. Jeppesen, 1993. Alternative equilibria in shallow lakes. Trends in Ecology and Evolution 8: 275-279.

Schriver, P., J. Bogestrand, E. Jeppesen \& M. Sondergaard, 1995. Impact of submerged macrophytes on fish-zooplankton-phytoplankton interactions - large-scale enclosure experiments in a shallow eutrophic lake. Freshwater Biology 33: 255-270.

Smol, J. P., 1988. Paleoclimate proxy data from freshwater arctic diatoms. Verhandlungen der Internationale Vereinigung der Limnologie 23: 837-844.

Sommer, U., J. Padisák, C. S. Reynolds \& P. Juhász-Nagy, 1993. Hutchinson's heritage: the diversity-disturbance relationship in phytoplankton. Hydrobiologia 249: 1-8.

Søndergaard, M. \& B. Moss, 1998. Impact of submerged macrophytes on phytoplankton in shallow freshwater lakes. In Jeppesen, E., Ma. Søndergaard, Mo. Søndergaard \& K. Christoffersen (eds), The Structuring Role of Submerged Macrophytes in Lakes. Ecological Studies, Vol. 131. Springer Verlag, New York: 115-132.

Teixeira-de Mello, F., M. Meerhoff, Z. Pekcan-Hekim \& E. Jeppesen, 2009. Substantial differences in littoral fish community structure and dynamics in subtropical and temperate shallow lakes. Freshwater Biology 54: 12021215.

Timms, R. M. \& B. Moss, 1984. Prevention of growth of potentially dense phytoplankton populations by zooplankton grazing, in the presence of zooplanktivorous fish, in a shallow wetland ecosystem. Limnology and Oceanography 29: 472-486.

Van Donk, E., R. D. Gulati, A. Iedema \& J. T. Meulemans, 1993. Macrophyte-related shifts in the nitrogen and phosphorus contents of the different trophic levels in a biomanipulated shallow lake. Hydrobiologia 251: 19-26.

Vanderstukken, M., S. Declerck, A. Pals, L. De Meester \& K. Muylaert, 2010. The influence of plant-associated filter feeders on phytoplankton biomass: a mesocosm study. Hydrobiologia 646: 199-208.

Vanormelingen, P., K. Cottenie, E. Michels, K. Muylaert, W. Vyverman \& L. De Meester, 2008. The relative importance of dispersal and local processes in structuring phytoplankton communities in a set of highly interconnected ponds. Freshwater Biology 53: 2170-2183.

Williams, W. D., 1998. Salinity as a determinant of the structure of biological communities in salt lakes. Hydrobiologia 381: 191-201. 